International Journal of Latest Trends in Engineering and Technology

Vol.(8)Issue(3), pp.258-262

DOI: http://dx.doi.org/10.21172/1.83.039

e-ISSN:2278-621X

\title{
ETHNOBOTANICAL STUDY OF DURGAMKONDA OF VELIGONDA HILL RANGE, EASTERN GHATS, ANDHRA PRADESH
}

\author{
K. V. Rami Reddy ${ }^{1}$, M. John Paul ${ }^{2}$ and Dr. SKM. Basha ${ }^{3}$
}

\begin{abstract}
Durgamkonda of Veligonda Hill Range, Eastern Ghats, Andhra Pradesh is floristically rich area where plants of various categories are growing spontaneously in their natural habitat. Durgamkonda is known for wide variety of Medicinal Plants that have been in existence identified and utilized since hundreds of years by local tribes. The present study aims at documentation of Medicinal Plants used by tribes for various purposes. Durgamkonda is the most important part of veligonda situated near Udayagiri forest of Nellore District.

Key words: Durgamkonda - Ethnobotany - Medicinal Plants -MPCA- Tribes.
\end{abstract}

\section{INTRODUCTION}

The area of Durgamkonda reserve forests covers aroung 5029.60 hectors of land. There is significant number of rare species of endemic flora and fauna, most of the area is under the conservation region. Udayagiri was also known as Kondyapalem in ancient times. It lies at the foot of Udayagiri hill which is about 938 meters above the sea level. The hill fort is supposed to have been built by Langula Gajapathi, a Hindu King.

Udayagiri is a mandal in Nellore district of Andhra Pradesh. Udayagiri hill (Sanjeevini hill) is situated on the southern part of Udayagiri town. It is the southernmost part of the Eastern Ghats. It comprised of dry deciduous forests and located at $14.8667^{\circ} \mathrm{N}, 79.3167^{\circ} \mathrm{E}$. It has an average elevation of $3261 \mathrm{ft}$ above the sea level. Durgampalli, Duragampalli road, Loddivagu (Loddi river), Salvapet, Kona canal, Kona,Tapaka, Chinna masjid (Small Mosque) Pedda masjid(Big Mosque) and fort are the main places of the hill. Herbarium species were deposited at Department of Botany, Vikrama Simhapuri University P. G Centre, Kavali.

\section{STUDY AREA}

Durgamkonda of Udayagiri Durgam is a sacred Groove and off shoots of Eastern ghats is an abode for rich Bio-diversity.Total number of plants in our study from udayagiri hills is 295 species of 290 genera and 83 families with genus-species ratio is 4.5:3.7:1 .The presence of 295 species concludes that udayagiri forests as one of the phyto-diversity rich spot of Nellore district. Dicotyledons are represented by 260 species belonging to 270 genera of 35 families. Monocotyledons include 30 speies belonging to 20 genera of 11 families.

The ratio of dicotylidons to monocotylidons is 10:1.For species and 10.3:1 for genus Based on habit flora comprises 121 species (37\%) under trees followed by 76 species shrubs (20\%) and 107 species herbs (31\%) and 37species of climbers (11\%).37\% of flora comprises trees , 33\% of flora comprises herbs $21 \%$ of flora comprises shrubs and $11 \%$ of flora comprises climbers.

Hardwickia binata and Pterocarpus santalinus occur here and there over the veligondas. Anogeissus latifolia occurs in patches in the slopes of yerra konda. The principal ranges of hills bearing forests of the veligondas, the

\footnotetext{
${ }^{1}$ Department of Botany, Rayalaseema University, Kurnool, Andhra Pradesh, India

${ }^{2}$ Research and Development Centre, Bharatiar University, Coimbatore, Tamilnadu, India

${ }^{3}$ Department of Botany, Vikrama Simhapuri University, Kavali, Nellore Dt, Andhra Pradesh, India
} 
yerrakonda and the Udayagiri duragam hills. The veligonda range, the yerrakonda ( yerra means Red) are called so because these hills contain a number of Hardwickia binata (yepi) trees. The young red leaves of these trees give a distinctive colour to their general aspect in summer.

Hardwickia binata is one of the dominant components in forests especially near foot hills and low elevation up to $300 \mathrm{~m}$ but due to over exploitation and slow regeneration it became threatened species in Veligonda hill range Much stress is given to collect data on use of these plants by tribals namely yanadis ,tribal medicine.The ethnomedical data was prepared from house-wives who knew/practice of herbal medicine, village physicians, tribals, Yanadi, Yerukula and Nakkala.

\section{EXPERIMENT AND RESULT}

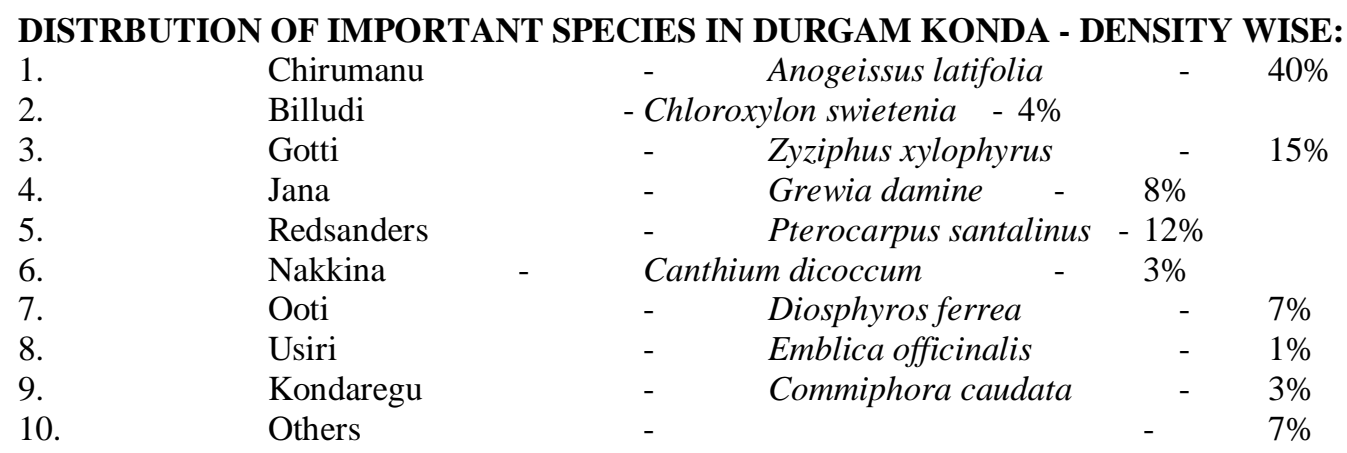

Important species found in Durgamkonda of Udayagiri hills

\begin{tabular}{|c|c|c|c|}
\hline 1. & Chirumanu & - & Anogeissus latifolia \\
\hline 2. & Billudu & - & Chloroxylon swietenia \\
\hline 3. & Gotti & - & Zyziphus xylophyrus \\
\hline 4. & Jana & \multicolumn{2}{|c|}{ Grewia damine } \\
\hline 5. & Redsanders & - & Pterocarpus santalinus \\
\hline 6. & Nakkina & & Canthium dicoccum \\
\hline 7. & Ooti & \multicolumn{2}{|c|}{ Diosphyros ferrea } \\
\hline 8. & Usiri & - & Emblica officinalis \\
\hline 9. & Mayuri siki & - & Actinopteris radiata \\
\hline 10. & Sarapappu & & Buchanania Lanzan \\
\hline 11. & Nelavemu & & Andrographis paniculata \\
\hline 12. & Musti & - & Strychnos nuxvomica \\
\hline 13. & Kunkudu & & Sapindus emarginatus \\
\hline 14. & velama & - & Anogeissus latifolia \\
\hline 15. & Rela & - & Cassia fistula \\
\hline 16. & Karaka & - & Terminalia chebula \\
\hline 17. & Beedi leaves & - & Diospyros Melanoxylon \\
\hline 18. & Maredu kommulu & & - $\quad$ Decalepis hamiltonii \\
\hline 19. & Beera & - & Luffa acutangula \\
\hline 20. & Kalivi & - & Carissa carandas \\
\hline 21. & Gumpena & & Lannea coromandelica \\
\hline 22. & Pala & \multicolumn{2}{|c|}{ Manikara Hexandra } \\
\hline 23. & Yepi & - & Hardwickia binata \\
\hline 24. & Munkudu & & Atlanta monophylla \\
\hline 25. & Magabeera & - & Anisomeles malabarica \\
\hline 26. & Somichettu & - & Soymida febrifuga \\
\hline 27. & Kondakasintha & - & Toddalia asiatica \\
\hline 28. & Adavi ulli & & Urginea indica \\
\hline 29. & Chedu jilakara & - & Vernonia anthelmintica \\
\hline 30. & Bodatharam & - & Sphaeranthus indicus \\
\hline 31. & Karrathumma & - & Prosopis chelelsis \\
\hline 32. & Chitramudam & - & Plumbago zeylanica \\
\hline 33. & Addasaram & - & Adathoda vasica \\
\hline
\end{tabular}


34. Tangedu - $\quad$ Cassia auriculata

\section{MINOR FOREST PRODUCTS OF DURGAMKONDA OF UDAYAGIRI HILLS OF VELIGONDA HILL RANGE}

Buchanania lanzan (Sarapappu) seed: - The species occurs scattered in all the ranges but the seeds are collected only in Udayagiri Range.

Strychnos nux-vomica (Musti) seed:- The species occur scattered in all the ranges. The ripe fruits are collected from December to April .The proper time to start the collection is when the bats begin to eat the fruits.

Sapindus emarginatus (Kunkudu) Fruits:- Fruits ripe in April and the collection is made in May. Fruits used as substitute of soap.

Tamarindus indica (Chinta) Fruits:- Trees occur in scattered manner in all the ranges. The fruits ripe in FebruaryMarch. Pods \& leaves are used for culinary purpose.

Murraya Koenigii (Karivepaku) Leaves:- The leaves are collected and dispatched to consumption centers in Udayagiri division as well as to Madras. Leaves are used to flavor curries etc.

Anogeissus latifolia (Chirumanu)wood: The only species which occur in fair profusion. Wood is used as Timber.

Cassia fistula (Rela) Bark:- The species occur diffusely in hilly tracts of Udayagiri hill range. Stem bark and fruit pulp are used as laxative.

Cassia auriculata (Tangedu) Bark:- The species occur diffusely in plain areas of Udayagiri range. Powdered root bark is taken internally for cooling effect.

Terminalia chebula (Karaka)Fruits:- The species is found in fair abundance in interior ranges of Udayagiri hills. Fruits of myrobalan are of medicinally important. Wood is a valuble timber.

Diospyros melanoxylon (Beedi aaku)Leaves:- These occurs diffusely in all the Udayagiri hill ranges. Leaves are used in the preparation of Beedis.

Accacia leucophloea (Tella thumma) Bark :- Bark is used for tanning and in alcohol distillation. Gum is indigenous medicine.

Viscum auriculatum (Badanika) Stem:- Paste of plant applied to wounds.

Terminalia bellerica (Thandra) Fruits :- Fruit is used as astringent and a remedy for cough. Wood used as timber.

Menecylon umbellatum (Alli)Leaves :- Yellow dye from the leaves used for dyeing clothes and mats.

Trichosanthes cucumerina (Adavi potla)Roots :- Roots used to cure bronchitis. Leaves used in bilious disorders. Mytragyna parvifolia (Batta Ganapa) Stem :- Wood used for furniture.

Terenna asiatica (Korivi) Leaves :- Leaves used in Skin deceases and swellings.

Wrightia tinctoria (Reppala) Bark :- Decoction of bark and leaves are taken for stomach disorders.

Hemidesmus indicus (Sugandhapala) Roots :- Roots used for cooling effect and blood purification.

Strychnos potarorum (Chilla) Seeds :- Seeds are used to clear turbid water and in eye diseases.

Lucas aspera (Tummi) Leaves:- Leaf juice used in treating jaundice and scorpion sting.

Plumbago zeylanica (Chitramulam) Root:- Roots used as appetizer and in skin diseases.

Salvadora persica (Varagogu) Leaves :- Twigs used as tooth cleaners, decoction of leaves in asthma and cough.

Gmelina asiatica (Gummadi) Fruits :- Ripe fruits used in removing dandruff.

Chionanthes zeylanica (Punagani) Roots :- Root bark used to control white discharge in ladies.

Boswellia serrata (Adavi sambrani):-Stem - stomach ulcers, diabetes. Leaf - mouth and throat ulcers. Gum dysentery, inflammations, joint pains, arthritis, amoebic, dysentery, hydrocele, diabetes.

Aegle marmelos (L) (Maredu):-Whole plant - Venereal diseases, digestive and abdominal disorders, eye diseases, stupor, pyrexia, dropsy, vomiting, piles, intermittent fever. Leaf - Diabetes, fruit astringent, digestive stomachic, dysentery cooling agent.

Gymnema sylvestre (Retz) (Podapatri):-Root - Hydrocele, polyuria, poisoning. Leaf- Diabetes, diuretic, fruit stomachic, alexitaric, bronchitis, cardiac diseases.

Gmelina arborea (Roxb) (Gummadi teku):- Root - Cardiac diseases, dysuria, aphrodisiac, expectorant, demulcent. Leaf -Diabetes. Fruit-Diabetes.

Gloriosa superba (L) (Adavi Nabhi):- Tuber - Tonic, stomachic, anthelmintic, abortifacient, gonorrhea, ulcers, neuralgic pains, skin troubles, gout, rheumatism, piles, skin diseases, leprosy, wounds, snake bite and scorpion string. Leaf juice-Lice killer.

Hardwickia binata Roxb :- Bark yields resinuous gum and fibre leaf used as green manure

Asparagus racemosus Wild (Pilliteegalu):- Tuber - Herbal tonic, diuretic, galactogogue, urinary diseases, gynaecological disorders, diseases of nervous system, hyperacidity, gastritis, menorrhagia, eye diseases. Root, leaf diabetes, cough, diarrhea, pain, skin diseases, nervous and rheumatic complaints. 
Andrograthis paniculata (Brum.f) (Nelavemu):- Whole plant - Febrifuge, astringent, anodyne, tonic, diabetes. Leaf - anthelmintic, malarial fever, skin diseases, general debility, discontinuation of menstrual cycle.

Tinospora cordifolia (Wild) (Kappa teega):- Root - Snake bite. Stem - Fissures in the sole, snake bite.

Cassia senna L (Senna):- Leaf and Fruit - Laxative, purgative, constipation, febrifuge, gout, worm infestation, skin diseases, abdominal and blood disorders.

Piper longum L (Pippallu):- Leaf and Fruit - Counter irritation, diabetes, analgesic, expectorant, inflammations, carminative, insomnia tonic, cough, cold, bronchitis, stimulant, lever disorders, fever, indigestion.

Santalum album L (Srigandhamu):- Heart wood and wood - Diabetes, oil- verenal diseases, refrigerant, expectorant, herpis worm infestation, dysuria.

Strychnos colubrina L. (Teega Mushti):- Wood - Fever. Root - Rheumatism, Anthelmintic, cutaneous disorders. Fruit - Mania.

Strychnos potatorum L.f (Chillaginja Chettu):- Seed - Tonic, diabetes, diarrhea, gonorrhea, cardiac diseases, abdominal diseases, stomachic, water purifier.

\section{VENDEMISM:}

A good number of plants seemed to be endemic to these parts of Eastern Ghats. But specific mention may be made of Pterocarus santalinus. It is an interesting species in that it is more prevalent in this area than in the adjoining districts viz. Kurnool and Chittoor. It has edaphic preference at higher elevations Shorea tumbaggaia is rare but occurs in this forests only, found associated with Red sanders at high elevation. Croton scabiosus is another associate of Red sanders. A few more endemics like Decalepis hamiltoni, Glossocardia, Sympagis petiolares, Hugonia mystax, Terminalia pallid, also occur in this forest.

Rare plants: Owing to intensive studies in the area a good number of species have been discovered first time or recorded after a lapse of at least seventy years. Some of them by their occurrence here show continuity or extended distribution in the Udayagiri Hills. Desmodium pryonii, Hibiscus purpureus, Rhynchosia rufesens, Rhynchosia rothii, Rhynchosia densiflora, Asyneuma fulgens.

From the foregoing information it is clear that the area harbours a good number endemics and rare plants. It seems to be due to a combination of factors of edaphic, climatic as well as genetic structure in total. Thus these parts of Eastern Ghats forming at ecological islands support specific gene pool niche. Any disturbance due to biotic interference leading to degradation of forests, the prevailing semi arid climate and thermal regime, give scope for thrival of exotics resulting in the unusual change in natural ecosystems

The field work carried out at intervals has facilitated the researcher to record the data in various surveys. The survey resulted in collection of more than 225 medicinal plants used for different ailments along with the ethno medicinal data from 30 informants.

The following are the vulnerable plants in Udayagiri hill range

$\begin{array}{lll}\text { 1. } & \text { Sterculia villosa } & \text { 7. Rubia cordifolia } \\ \text { 2. } & \text { Aegle marmelos } & \text { 8. Eubhorbia fusiformis } \\ \text { 3. } & \text { Gymnema sylvestre } & \text { 9. Stemona tuberosa } \\ \text { 4. } & \text { Oroxylum indicum } & \text { 10. Hildergardia populifolia } \\ \text { 5. } & \text { Gloriosa superba } & \text { 11. Phyllanthus indofischeri } \\ \text { 6. } & \text { Shorea tumbuggaia }\end{array}$

\section{IV.CONCLUSION}

Ethnobotanical study of a particular region depicts its ecological, hydrological. Topographical, historical identification. Documentation of all indentified species of Durgamkonda of Udayagiri forest in the present study would serve as a reference for the students and teachers of Botany and others interested to get knowledge. This study also helps in the addition of new species to district flora. For the proper utilizing of forest resources, meticulous and estimated strategy need to be evolved without causing deterioration to the flora. There are efforts to develop infrastructure like Roads, electricity etc... To make this as one of the best tourist spot in the State. It can be developed as Andhra Ooty, if funds allotted. The climatic condition is semi arid with mixed type of vegetation consists of semi evergreen dry deciduous scrub forest. Hence it is suitable Medicinal plant conservative area.

\section{REFERENCES}

[1] Basha SKM, Rajyalakmi. E 2012, Floristic Wealth of Nelapattu Bird Sanctuary, Nellore Dist, A.P. Journal Economic Taxon Bot.vol 36 No:1, 2012.

[2] Bentham, G \& J.D.Hooker 1862-1883.Genera Plantarium. 3 vols. London 
[3] Ethnobotanical Leaflets 14:420-26-,2010

[4] Champion H.G. \& S.K. Seth 1968. A revised survey of the forest types of India. Govt. of India, Delhi.

[5] Gamble J.S (1957) Flora of the presidency of Madras, Vols I-II, BSI, Calcutta.

Rao, C.K. 1972. Angiospermic genera endemic to the Indian floristic region and its neighbouring areas.Ind.Forester.98:560-566.

[6] Jain, S.K. and Rao, R.R (1977) A hand book of field herbarum methods Today and Tomorrow and Publishers, New Delhi - pp1-157.

[7] Surya Narayana, B. and Sreenivasa Rao, A. (2002), Flora of Nellore District, Andhra Pradesh, Pub, Maharashtra.

[8] Roxburgh, W. (1795-1818). Plants of the Coast of Coramandel. Vol.3. Nicolson, London. 